\title{
Article \\ Relationship between the Phenylpropanoid Pathway and Dwarfism of Paspalum seashore Based on RNA-Seq and iTRAQ
}

\author{
Yong Zhang, Jun Liu, Jingjin Yu, Huangwei Zhang and Zhimin Yang* \\ College of Agro-Grassland Science, Nanjing Agricultural University, Nanjing 210095, China; \\ 2018220006@njau.edu.cn (Y.Z.); liujun825@njau.edu.cn (J.L.); jingiin_yu@126.com (J.Y.); \\ 2020220006@stu.njau.edu.cn (H.Z.) \\ * Correspondence: nauyzm@njau.edu.cn; Tel.: +86-1380-158-9708
}

Citation: Zhang, Y.; Liu, J.; Yu, J.; Zhang, H.; Yang, Z. Relationship between the Phenylpropanoid Pathway and Dwarfism of Paspalum seashore Based on RNA-Seq and iTRAQ. Int. J. Mol. Sci. 2021, 22, 9568. https://doi.org/10.3390/ ijms22179568

Received: 2 July 2021

Accepted: 31 August 2021

Published: 3 September 2021

Publisher's Note: MDPI stays neutral with regard to jurisdictional claims in published maps and institutional affiliations.

Copyright: (c) 2021 by the authors. Licensee MDPI, Basel, Switzerland. This article is an open access article distributed under the terms and conditions of the Creative Commons Attribution (CC BY) license (https:// creativecommons.org/licenses/by/ $4.0 /)$.

\begin{abstract}
Seashore paspalum is a major warm-season turfgrass requiring frequent mowing. The use of dwarf cultivars with slow growth is a promising method to decrease mowing frequency. The present study was conducted to provide an in-depth understanding of the molecular mechanism of T51 dwarfing in the phenylpropane pathway and to screen the key genes related to dwarfing. For this purpose, we obtained transcriptomic information based on RNA-Seq and proteomic information based on iTRAQ for the dwarf mutant T51 of seashore paspalum. The combined results of transcriptomic and proteomic analysis were used to identify the differential expression pattern of genes at the translational and transcriptional levels. A total of 8311 DEGs were detected at the transcription level, of which 2540 were upregulated and 5771 were downregulated. Based on the transcripts, 2910 proteins were identified using iTRAQ, of which 392 (155 upregulated and 237 downregulated) were DEPs. The phenylpropane pathway was found to be significantly enriched at both the transcriptional and translational levels. Combined with the decrease in lignin content and the increase in flavonoid content in T51, we found that the dwarf phenotype of T51 is closely related to the abnormal synthesis of lignin and flavonoids in the phenylpropane pathway. CCR and HCT may be the key genes for T51 dwarf. This study provides the basis for further study on the dwarfing mechanism of seashore paspalum. The screening of key genes lays a foundation for further studies on the molecular mechanism of seashore paspalum dwarfing.
\end{abstract}

Keywords: RNA-Seq; iTRAQ; dwarfism; phenylpropanoid; Paspalum seashore; lignin

\section{Introduction}

Seashore paspalum (Paspalum vaginatum Swartz) is a perennial herb of Paspalum L., which is native to North and South America [1]. It is also one of the most widely used warm-season turfgrasses in tropical and subtropical climates [2]. Compared with other grasses, seashore paspalum is advantageous due to its excellent tolerance to salt, drought, waterlogging, barren land, and wear [3]. Mowing, as the most basic cultural practice applied to turf, is labor-intensive and time-consuming. Several plant growth regulators, such as ethephon, trinexapac-ethyl, and endothal have been developed and applied to turf to reduce or slow the growth of grasses, thus decreasing the mowing required. An alternative to decrease mowing frequency is to develop dwarf grass cultivars.

Dwarfism, an important agronomic trait, has been studied extensively in field crops and model plants such as rice (Oryza sativa Larfism) [4], wheat (Triticum aestivum L.) [5], and Arabidopsis (Arabidopsis thaliana L.) [6].It has been shown that most dwarfing genes regulate the balance of endogenous phytohormone(s) to disturb cell proliferation and/or cell expansion, thus resulting in dwarfism [7-10].

In addition to these phytohormone-related dwarfing genes and mechanisms, the phenylpropanoid pathway is also involved in dwarfism [11,12]. The phenylpropane pathway is a universal pathway in the secondary metabolism of plants, catalyzed by more 
than 10 enzymes, mainly including phenylalanine ammonialyase (PAL), cinnamate 4hydroxylase $(\mathrm{C} 4 \mathrm{H})$, caffeoyl shikimate esterase $(\mathrm{CSE})$, coumarate 3-hydroxylase $(\mathrm{C} 3 \mathrm{H})$, ferulate-5-hydroxylase (F5H), 4-coumarate CoA ligase (4CL), coumaroyl-coenzyme A-3hydroxylase $(\mathrm{CCH})$, caffeic acid 3-O-methyl transferase (COMT), cinnamoy1-CoA reductase (CCR), cinnamyl alcohol dehydrogenase (CAD), sinapyl alcohol dehydrogenase (SAD), cafeoy1-CoA3-O-methy1transferase (CCoAOMT), and hydroxycinnamoyl CoA:shikimate hydroxycinnamoyl transferase (HCT). Phenylpropanoid metabolism in plants mainly includes phenylalanine metabolism and the synthesis of secondary metabolites such as lignin and flavonoids. Studies have shown that plant dwarfing through the phenylpropane pathway usually leads to a decrease in lignin content, some of which is accompanied by an increase in flavonoid content. Knockout of S-adenosyl-L-homocysteine hydrolase (SAHH) results in dwarfism with increasing cytokinin (CK) [13-15]. Silencing of CAD in Brachypodium distachyon causes dwarfism with decreasing lignin content [16]. Silencing of HCT in Arabidopsis results in dwarfism by accumulating endogenous flavonoid [17]. Downregulation of CCR1 in Salvia miltiorrhiza Bunge causes dwarfism with decreasing lignin content [18].

RNA-Seq is an essential tool for analyzing differential gene expression and gene regulatory networks at the transcriptional level. It has also been widely used in plants lacking complete genomic information to find transcriptional evidence [19-21]. At present, RNA-Seq has been applied to determine the molecular mechanism of dwarfing regulation in Kentucky Bluegrass [22], Brassica [23], napus pear [24], and other plants, as well as the mining of dwarfing-related genes. Proteomic analyses, providing translational insights, have also been widely used in determining proteomics of dwarfing mutants to quickly find dwarfing-related proteins [25-27]. Many different methods can be used to compare protein levels, among which isobaric tags for relative and absolute quantitation (iTRAQ) is receiving increasing attention. Since iTRAQ can quantitatively analyze almost any protein sample and has higher sensitivity and high quantitative accuracy, it has become an increasingly widely used quantitative proteomics technology [28]. This method uses relative and absolute isobaric quantification techniques. Compared with two-dimensional electrophoresis (2-DE), isotopic affinity labeling (ICAT), and differential gel electrophoresis (DIGE) methods, iTRAQ provides improved quantitative repeatability and higher sensitivity and is therefore more widely used in proteomics research [29]. Additionally, the results of RNA-Seq can facilitate the identification of novel and known proteins and their roles in target traits [30,31].

The scarcity of genome information poses an obstacle to developing new cultivars of seashore paspalum by modern genetic and genomic methods [32]. For non-model species such as seashore paspalum that lack the sequenced genome, RNA-Seq is a valuable tool for the development of new genetic resources. To the best of our knowledge, there are some applications of RNA-Seq technology in seashore paspalum [33]; however, reports on the RNA-Seq of dwarfing mutants of seashore paspalum are lacking, and the iTRAQ of seashore paspalum has not been reported. In this study, we combined RNA-Seq and iTRAQ to construct unique transcripts and proteomes of T51 and WT and then screened dwarfism-related genes and proteins to understand the dwarfing mechanism of T51. To the best of our knowledge, this study provides the first transcriptome and proteome profile for dwarfing mutants of seashore paspalum, laying the foundation for screening the genes related to turf dwarfs in the future.

\section{Results}

\subsection{Phenotypic Characterization of T51 and WT}

Compared with WT, T51 showed a dwarf phenotype (Figure 1). The plant height of T51 was significantly shorter than that of WT (Table 1). In addition, the lengths of the leaves and erect stem of T51 were significantly shorter than those of WT (Table 1). 

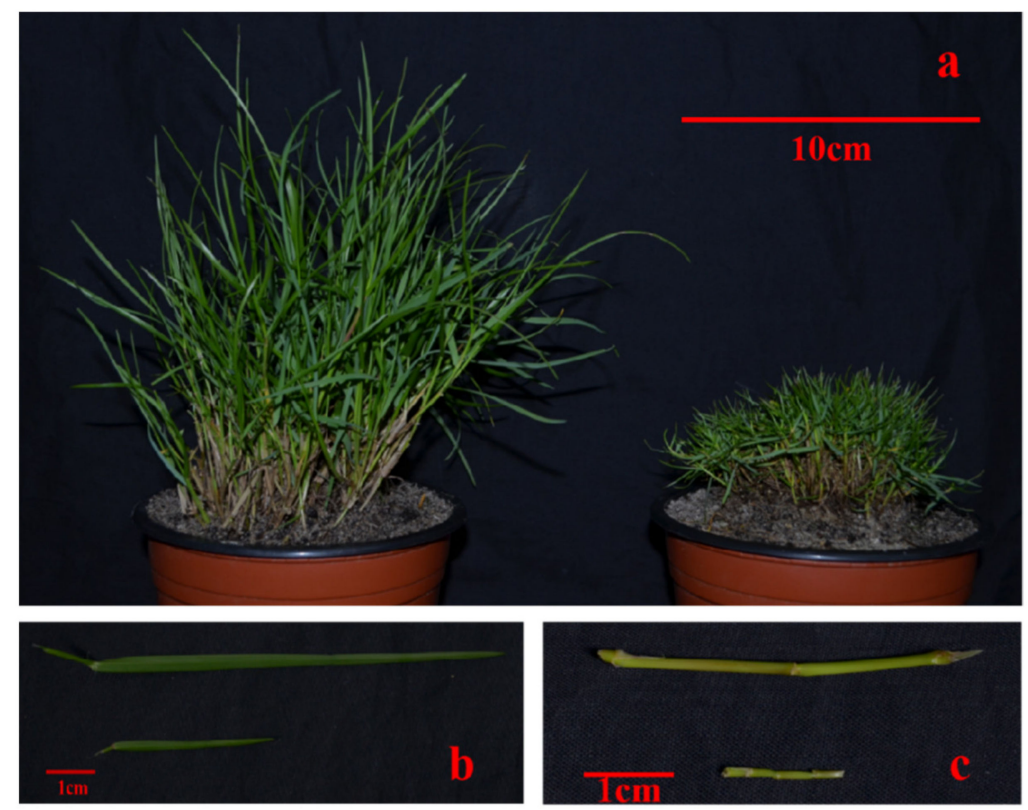

Figure 1. Phenotypic differences between WT and T51. (a) Plant types of WT and T51. (b) Leaves of WT and T51. (c) Erect stem of WT and T51.

Table 1. Statistical analysis of morphological differences between WT and T51.

\begin{tabular}{cccccc}
\hline Material & Plant Height & Leaf Length & Leaf Width & $\begin{array}{c}\text { Internode } \\
\text { Length }\end{array}$ & $\begin{array}{c}\text { Diameter } \\
\text { Width }\end{array}$ \\
\hline WT & $13.91 \mathrm{a}$ & $7.74 \mathrm{a}$ & $2.16 \mathrm{a}$ & $1.30 \mathrm{a}$ & $1.19 \mathrm{a}$ \\
T51 & $4.12 \mathrm{~b}$ & $3.29 \mathrm{~b}$ & $1.97 \mathrm{~b}$ & $0.36 \mathrm{~b}$ & $0.90 \mathrm{~b}$ \\
\hline
\end{tabular}

Note: using Tukey's HSD post hoc test. a,b represent significant difference between treatments.

\subsection{Transcriptional Analysis of DEGs}

To verify transcriptional-level changes, two cDNA libraries (i.e., WT and T51) were constructed using the total RNA extracted from the leaves of WT and T51. After removing low-quality reads and adaptor sequences, $66.41,64.50,53.53,53.51,48.88$, and 65.56 million clean reads were obtained for T51-1, T51-2, T51-3, WT-1, WT-2, and WT-3, respectively, with $76.33 \%, 74.88 \%, 75.17 \%, 75.31 \%, 74.88 \%$, and $76.18 \%$ of the reads mapped to the reference sequence, respectively, which was a transcriptome assembled by Trinity (Table S1). Finally, 54,573 unique genes were detected in T51_WT (Table S1). The DEGs were filtered with FDR $<0.05, \mid \log _{2}$ fold-change $\mid>1$ in T51_WT for comparison. Compared with the WT group, the T51 group had 8311 (2540 upregulated and 5771 downregulated) significant DEGs (Figure 2A).

\subsection{Identification of DEPs Using iTRAQ Technology}

The DEPs in T51_WT comparison were identified and quantified using ITRAQ and LC-MS/MS analysis. Accordingly, 384,388 spectra were generated, and 23,271 unique peptides and 2910 proteins were identified with an unused score of $\geq 1.3$ and $\% \mathrm{Cov} \geq 95$ (Table S2). Among these proteins, there were 392 (155 upregulated and 237 downregulated) DAPs in T51_WT, with a fold-change of $\geq 1.5$ (mean value of all compared groups) or $\leq 0.67$ and a $p$-value (z-test of all comparison groups) of $\leq 0.05$ (Figure 2B). 

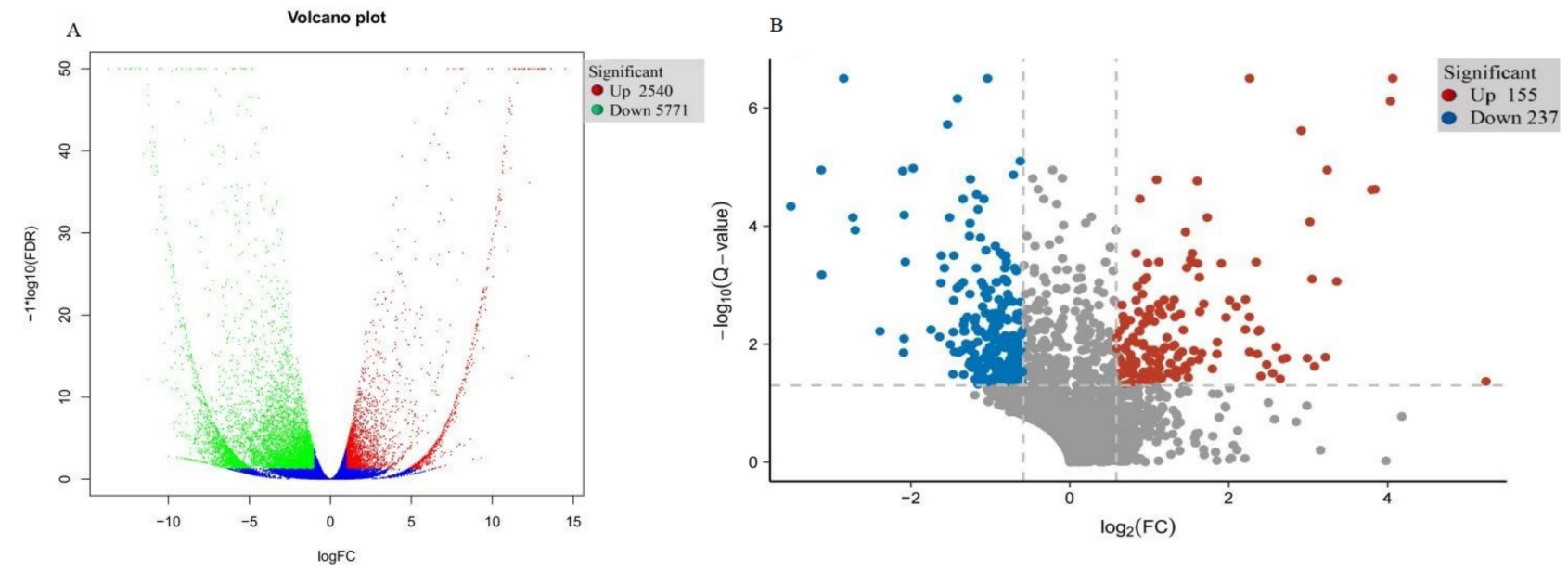

Figure 2. (A) Expression pattern of differentially expressed genes in T51 and WT. (B) Expression pattern of differentially expressed proteins in T51 and WT.

\subsection{Correlation Analysis between the Transcriptome and Proteome Data}

An expression correlation analysis was performed between the DEPs and their corresponding DEGs (Figure 3). The detailed correlation analysis results are shown in the Supplementary Data (Table S3) Overall, most of the DEGs and DEPs showed no corresponding correlation. Among those DEGs/DEPs, 13 exhibited common upregulated expression tendency, 7 exhibited a common downregulated expression tendency, 45 exhibited downregulated expression at the proteome level and upregulated expression at the transcriptome level, 37 exhibited upregulated expression at the proteome level and downregulated expression at transcriptome level, 179 exhibited downregulation at proteome level and no difference at the transcriptome level, and 111 exhibited upregulation at the proteome level and no difference at the transcriptome level.

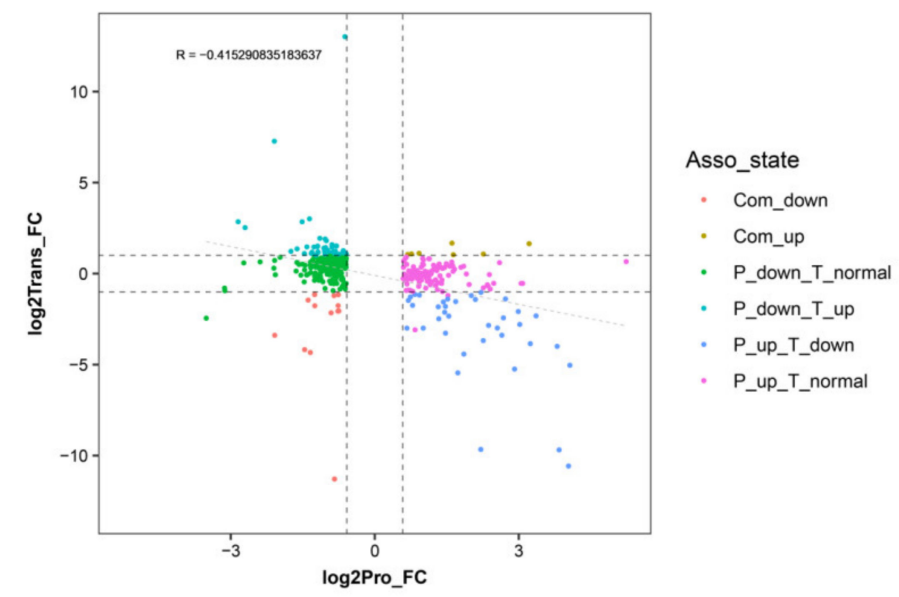

Figure 3. Correlation analysis between differentially expressed genes and proteins in WT and T51 samples. The $x$-axis illustrates the expression pattern of the differentially expressed proteins (DEPs), and the $y$-axis illustrates the expression pattern of their corresponding DEGs in WT and T51 samples.

\subsection{KEGG Pathway Enrichment Analysis of DEGs and DEPs}

To annotate the functions of genes and proteins, we conducted a pathway enrichment analysis of the DEGs and DEPs in T51_WT based on the KEGG database. DEGs were significantly enriched in 24 pathways (Table 2), with the highest enrichment and the largest number of DEGs in ribosome and phenylpropane pathways. In addition, the DEGs also showed enrichment in plant hormone signal transduction pathways and flavonoid biosynthesis pathways. 
Table 2. KEGG pathway enrichment analysis of DEGs in seashore paspalum.

\begin{tabular}{lccc}
\hline Pathway ID & Pathway Name & $\begin{array}{c}\text { Gene } \\
\text { Number }\end{array}$ & $p$-Value \\
\hline ko03010 & Ribosome & 305 & $1.89 \times 10^{-16}$ \\
ko00940 & Phenylpropanoid biosynthesis & 91 & $3.47 \times 10^{-11}$ \\
ko00941 & Flavonoid biosynthesis & 28 & $6.48 \times 10^{-6}$ \\
ko00982 & Drug metabolism-cytochrome P450 & 33 & $5.60 \times 10^{-4}$ \\
ko01524 & Platinum drug resistance & 35 & $5.84 \times 10^{-4}$ \\
ko00460 & Cyanoamino acid metabolism & 20 & $1.28 \times 10^{-3}$ \\
ko00980 & Metabolism of xenobiotics by cytochrome P450 & 31 & $1.62 \times 10^{-3}$ \\
k005204 & Chemical carcinogenesis & 30 & $2.23 \times 10^{-3}$ \\
ko05016 & Huntington's disease & 83 & $2.32 \times 10^{-3}$ \\
ko04075 & Plant hormone signal transduction & 58 & $5.12 \times 10^{-3}$ \\
ko05012 & Parkinson's disease & 70 & $5.23 \times 10^{-3}$ \\
k000592 & alpha-Linolenic acid metabolism & 24 & $6.98 \times 10^{-3}$ \\
ko05010 & Alzheimer's disease & 73 & $1.37 \times 10^{-2}$ \\
ko00945 & Stilbenoid, diarylheptanoid and gingerol & 12 & $1.48 \times 10^{-2}$ \\
ko04260 & biosynthesis & 18 & $1.52 \times 10^{-2}$ \\
ko04020 & Cardiac muscle contraction & 27 & $1.69 \times 10^{-2}$ \\
ko00904 & Calcium signaling pathway & 8 & $2.14 \times 10^{-2}$ \\
ko05134 & Diterpenoid biosynthesis & 46 & $2.32 \times 10^{-2}$ \\
ko04915 & Legionellosis & 32 & $2.68 \times 10^{-2}$ \\
ko00073 & Estrogen signaling pathway & 11 & $3.04 \times 10^{-2}$ \\
k001040 & Cutin, suberine, and wax biosynthesis & 21 & $3.05 \times 10^{-2}$ \\
ko00909 & Sesquiterpenoid and triterpenoid biosynthesis & 7 & $3.25 \times 10^{-2}$ \\
ko01220 & Degradation of aromatic compounds & 9 & $3.91 \times 10^{-2}$ \\
ko00944 & Flavone and flavonol biosynthesis & 4 & $3.93 \times 10^{-2}$ \\
\hline
\end{tabular}

DEPs were significantly enriched in 17 pathways (Table 3), with the highest enrichment and the largest number of DEPs in metabolic pathways and biosynthesis of secondary metabolites pathways. In addition, DEPs showed enrichment in phenylpropanoid biosynthesis pathways and flavonoid phenylalanine metabolism pathways. Comparative analysis indicated that the phenylpropanoid biosynthesis pathway is a common pathway between the transcriptome and proteome, so it was further investigated as a candidate pathway for dwarfing research.

Table 3. KEGG pathway enrichment analysis of DEPs in seashore paspalum.

\begin{tabular}{|c|c|c|c|c|c|}
\hline Pathway ID & Pathway Name & $p$-Value & $\begin{array}{l}\text { Protein } \\
\text { Number }\end{array}$ & $\begin{array}{c}\text { Up } \\
\text { Number }\end{array}$ & $\begin{array}{l}\text { Down } \\
\text { Number }\end{array}$ \\
\hline ko01100 & Metabolic pathways & $3.10 \times 10^{-6}$ & 135 & 51 & 84 \\
\hline ko01110 & $\begin{array}{l}\text { Biosynthesis of secondary } \\
\text { metabolites }\end{array}$ & $1.80 \times 10^{-4}$ & 84 & 37 & 47 \\
\hline ko00906 & Carotenoid biosynthesis & $7.70 \times 10^{-4}$ & 8 & 1 & 7 \\
\hline ko00360 & Phenylalanine metabolism & $1.55 \times 10^{-3}$ & 15 & 9 & 6 \\
\hline ko00910 & Nitrogen metabolism & $2.79 \times 10^{-3}$ & 8 & 4 & 4 \\
\hline ko00940 & $\begin{array}{l}\text { Phenylpropanoid } \\
\text { biosynthesis }\end{array}$ & $4.44 \times 10^{-3}$ & 20 & 14 & 6 \\
\hline ko00950 & $\begin{array}{l}\text { Isoquinoline alkaloid } \\
\text { biosynthesis }\end{array}$ & $5.97 \times 10^{-3}$ & 5 & 2 & 3 \\
\hline ko00196 & $\begin{array}{l}\text { Photosynthesis—antenna } \\
\text { proteins }\end{array}$ & $6.49 \times 10^{-3}$ & 6 & 0 & 6 \\
\hline ko01120 & $\begin{array}{l}\text { Microbial metabolism in } \\
\text { diverse environments }\end{array}$ & $8.48 \times 10^{-3}$ & 45 & 16 & 29 \\
\hline ko00710 & $\begin{array}{l}\text { Carbon fixation in } \\
\text { photosynthetic organisms }\end{array}$ & $1.64 \times 10^{-2}$ & 15 & 3 & 12 \\
\hline
\end{tabular}


Table 3. Cont.

\begin{tabular}{|c|c|c|c|c|c|}
\hline $\begin{array}{l}\text { Pathway } \\
\text { ID }\end{array}$ & Pathway Name & $p$-Value & $\begin{array}{l}\text { Protein } \\
\text { Number }\end{array}$ & $\begin{array}{c}\text { Up } \\
\text { Number }\end{array}$ & $\begin{array}{l}\text { Down } \\
\text { Number }\end{array}$ \\
\hline ko00740 & Riboflavin metabolism & $1.95 \times 10^{-2}$ & 3 & 2 & 1 \\
\hline ko00960 & $\begin{array}{l}\text { Tropane, piperidine, and } \\
\text { pyridine alkaloid biosynthesis }\end{array}$ & $2.17 \times 10^{-2}$ & 5 & 2 & 3 \\
\hline ko00250 & $\begin{array}{l}\text { Alanine, aspartate, and } \\
\text { glutamate metabolism }\end{array}$ & $2.54 \times 10^{-2}$ & 9 & 2 & 7 \\
\hline ko04146 & Peroxisome & $2.88 \times 10^{-2}$ & 10 & 7 & 3 \\
\hline ko00590 & Arachidonic acid metabolism & $3.51 \times 10^{-2}$ & 3 & 0 & 3 \\
\hline ko00030 & Pentose phosphate pathway & $3.66 \times 10^{-2}$ & 9 & 5 & 4 \\
\hline ko00350 & Tyrosine metabolism & $4.17 \times 10^{-2}$ & 6 & 3 & 3 \\
\hline
\end{tabular}

\subsection{Phenylpropanoid Biosynthesis Pathway}

In the phenylpropanoid pathway, 91 genes and 20 proteins were found to be differentially expressed. The relationship between the DEPs and their corresponding genes is shown in Table 4, in which two DEPs are annotated as PAL, one DEP is annotated as 4CL, two DEPs are annotated as CCR, one DEP is annotated as HCT, four DEPs are annotated as UGT72E, one DEP is annotated as BRT1, one DEP is annotated as F5H, and eight DEPs are annotated as peroxidase. Among them, PAL, 4CL, CCR, HCT, and F5H are the key enzymes of lignin synthesis.

Table 4. Differential expression proteins and their corresponding genes in phenylpropane pathway.

\begin{tabular}{|c|c|c|c|}
\hline Protein/Gene Number & KEGG (Ko_id and Definition) & Name & Associated State \\
\hline TRINITY_DN54911_c1_g2 & $\begin{array}{c}\text { K10775//phenylalanine } \\
\text { ammonia-lyase (EC:4.3.1.24) }\end{array}$ & PAL & Com_up \\
\hline TRINITY_DN53461_c6_g1 & $\begin{array}{l}\text { K10775//phenylalanine } \\
\text { ammonia-lyase (EC:4.3.1.24) }\end{array}$ & PAL & P_up_T_normal \\
\hline TRINITY_DN47018_c0_g1 & $\begin{array}{l}\text { K01904/ /4-coumarate-CoA ligase } \\
\text { (EC:6.2.1.12) }\end{array}$ & $4 \mathrm{CL}$ & P_up_T_down \\
\hline TRINITY_DN49758_c1_g1 & $\begin{array}{l}\text { K09753//cinnamoyl-CoA } \\
\text { reductase (EC:1.2.1.44) }\end{array}$ & CCR & P_up_T_normal \\
\hline TRINITY_DN42134_c0_g1 & $\begin{array}{l}\text { K09753//cinnamoyl-CoA } \\
\text { reductase (EC:1.2.1.44) } \\
\text { K13065//shikimate }\end{array}$ & CCR & P_down_T_up \\
\hline TRINITY_DN50277_c0_g1 & $\begin{array}{l}\text { O-hydroxycinnamoyltransferase } \\
\text { (EC:2.3.1.133) }\end{array}$ & HCT & P_down_T_up \\
\hline TRINITY_DN54341_c1_g7 & $\begin{array}{l}\text { K12356//coniferyl-alcohol } \\
\text { glucosyltransferase (EC:2.4.1.111) }\end{array}$ & UGT72E & P_up_T_down \\
\hline TRINITY_DN51643_c2_g1 & $\begin{array}{l}\text { K12356//coniferyl-alcohol } \\
\text { glucosyltransferase (EC:2.4.1.111) }\end{array}$ & UGT72E & P_up_T_normal \\
\hline TRINITY_DN51903_c2_g2 & $\begin{array}{l}\text { K12356//coniferyl-alcohol } \\
\text { glucosyltransferase (EC:2.4.1.111) }\end{array}$ & UGT72E & P_up_T_normal \\
\hline TRINITY_DN53983_c2_g4 & $\begin{array}{l}\text { K12356//coniferyl-alcohol } \\
\text { glucosyltransferase (EC:2.4.1.111) }\end{array}$ & UGT72E & P_up_T_normal \\
\hline TRINITY_DN53754_c2_g1 & $\begin{array}{c}\text { K13068// sinapate 1 } \\
\text {-glucosyltransferase (EC:2.4.1.120) }\end{array}$ & BRT1 & P_up_T_normal \\
\hline TRINITY_DN51271_c1_g1 & $\begin{array}{l}\text { K09755 / / ferulate-5-hydroxylase } \\
\text { (EC:1.14.--.) }\end{array}$ & $\begin{array}{l}\text { CYP84A, } \\
\text { F5H }\end{array}$ & P_down_T_normal \\
\hline TRINITY_DN53699_c3_g12 & K00430//peroxidase (EC:1.11.1.7) & E1.11.1.7 & P_up_T_down \\
\hline TRINITY_DN50408_c1_g11 & K00430//peroxidase (EC:1.11.1.7) & E1.11.1.7 & P_up_T_normal \\
\hline TRINITY_DN51250_c1_g6 & K00430//peroxidase (EC:1.11.1.7) & E1.11.1.7 & P_up_T_down \\
\hline TRINITY_DN50972_c4_g6 & K00430//peroxidase (EC:1.11.1.7) & E1.11.1.7 & P_up_T_normal \\
\hline TRINITY_DN53699_c3_g7 & K00430//peroxidase (EC:1.11.1.7) & E1.11.1.7 & P_up_T_normal \\
\hline TRINITY_DN50972_c2_g1 & K00430//peroxidase (EC:1.11.1.7) & E1.11.1.7 & P_down_T_normal \\
\hline TRINITY_DN50548_c3_g1 & K00430//peroxidase (EC:1.11.1.7) & E1.11.1.7 & P_down_T_normal \\
\hline TRINITY_DN50548_c2_g2 & K00430//peroxidase (EC:1.11.1.7) & E1.11.1.7 & Com_down \\
\hline
\end{tabular}

\subsection{Validation of RNA-Seq Results}

The expression levels of six genes, including TRINITY_DN 54911_c1_g2(PAL), TRINITY_DN 47018_c0_g1(4CL), TRINITY_DN 42134_c0_g1 (CCR), TRINITY_DN 50548_c2_g2 
(peroxidase, EC:1.11.1.7), and TRINITY_DN54341_c1_g7 (coniferyl-alcohol glucosyltransferase, EC:2.4.1.111), and TRINITY_DN 50277_c0_g1(HCT) were determined by quantitative realtime polymerase chain reaction (qRT-PCR). The expression patterns were similar to those generated from high-throughput sequencing, indicating the reliability of our transcriptome profiling data (Supplementary Materials Figure S1). The trends in the expression levels of $4 C L, C C R, H C T$, and coniferyl-alcohol glucosyltransferase (EC:2.4.1.111) revealed by qRT-PCR were inconsistent with the changes in the abundance of their encoded proteins as detected in the iTRAQ analysis. These results suggested that deep sequencing represents an accurate and efficient method for analyzing seashore paspalum gene expression levels and the abundance of their corresponding proteins.

\subsection{Difference in the Lignin and Flavone Contents in the Leaves of T51 and WT}

Since two DEPs were upregulated in the flavonoid pathway (Table S4), and three DEPs were downregulated in the lignin synthesis pathway, the contents of flavonoid and lignin differed between T51 and WT. The difference in the lignin content between T51 and WT was confirmed by the content of Klason lignin, which was significantly lower in T51 than in WT (Figure 4A); the content of flavonoid in T51 was significantly higher than in WT (Figure 4B).
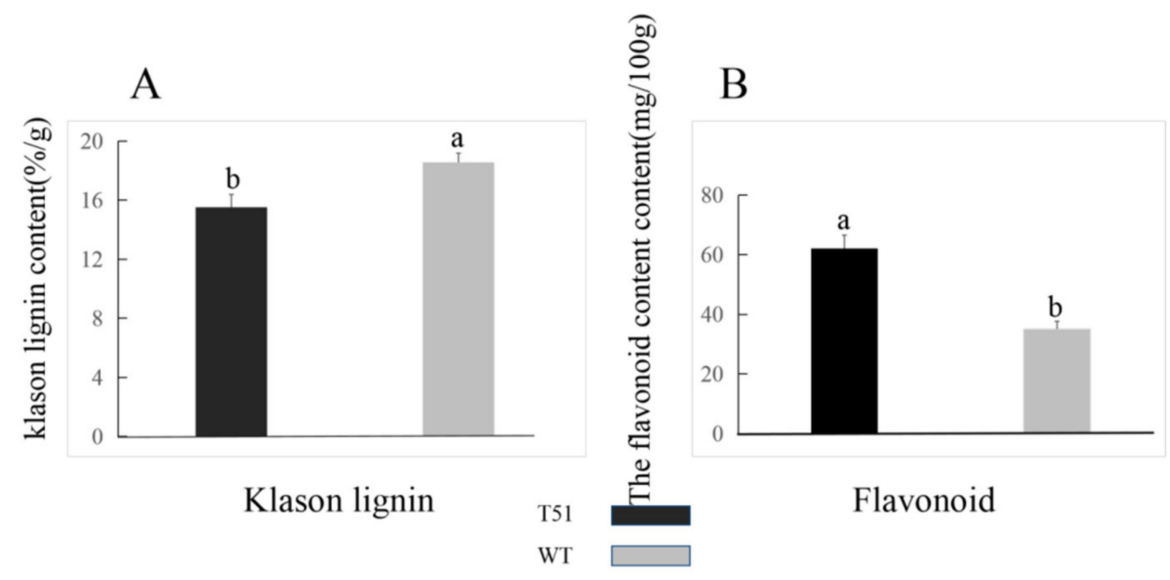

Figure 4. (A) Klason lignin contents. (B) Flavonoid contents. Vertical lines above the means bars indicate standard error $(n=3 ; p<0.05)$ using Tukey's HSD post hoc test; a,b represent significant differences between treatments.

\section{Discussion}

Comprehensive quantitative proteomics and transcriptomics analysis showed that there are more DEGs than DEPs in T51_WT, and only a few DEGs encode DEPs. These results are similar to those reported in pomegranate [34], potato [35], and orchid [36]. The trend in the transcription level is not consistent with that of protein abundance. These results indicate that protein abundance is affected by post-translational modifications and cell splicing events, rather than changes in gene transcription [37]. Correlation analysis showed that protein abundance is negatively correlated with the expression level of the corresponding genes (Figure 3). An earlier study also reported a relatively poor correlation between transcriptome and proteomic data [38]. One possible explanation for the low correlation between the transcription level and protein abundance is that the transcription level fluctuates more quickly than that of protein translation and modification. Therefore, the change in protein abundance occurs after the level of corresponding transcripts was stable [36]. Our results suggest that iTRAQ and transcriptome analysis are complementary methods for analyzing candidate proteins involved in specific physiological processes, including dwarfing of seashore paspalum.

A KEGG pathway enrichment analysis was completed to avoid false positive results, and the common pathways, namely the phenylpropane pathway, shared by DEPs and 
DEGs were selected for further study. In plants, the phenylpropane biosynthesis pathway can be divided into the common pathway and the specific pathway.

PAL is the first enzyme in the public phenylalanine biosynthesis pathway. In many plants, $P A L$ is encoded by polygene family members and plays different roles in phenylpropane metabolism $[39,40]$. PAL1 and PAL2 were proven to be related to the synthesis of lignin and flavonoids in Arabidopsis thaliana, so the activity of $P A L$ is a key factor in the synthesis of many phenolic compounds and lignin [41,42]. Inhibition of PAL activity is often accompanied by abnormal growth. For example, transgenic tobacco, which inhibits $P A L$ expression, shows a decrease in lignin content, and the growth and development of plants are also seriously affected [43,44]. Reducing PAL gene activity in Arabidopsis leads to extreme dwarfing and sterility [45]. The last key enzyme in the phenylpropanoid public metabolism pathway is $4 \mathrm{CL}$, which usually exists in plants as a gene family [46]. Different plants have different $4 C L$ functions, but the lignin content of transgenic plants that inhibits $4 C L$ activity shows a downward trend. Inhibition of $4 C L$ activity leads to the decrease in lignin content in tobacco and Arabidopsis; transgenic Arabidopsis grew normally, but transgenic tobacco showed dwarfing [47,48]. Compared with WT, two PAL proteins and one 4CL protein in T51 were upregulated, indicating that PAL and 4CL are not the reason for the decrease in lignin content in T51.

CCR is the first key enzyme in the specific pathway of lignin synthesis. According to the current cloned plant $C C R$ genes, $C C R 1$ is mainly related to lignin synthesis, whereas $C C R 2$ is mainly related to plant stress resistance [49]. Transgenic tobacco, with serious $C C R$ activity downregulation, not only showed a significant decrease in lignin content (the decrease in $\mathrm{G}$ content resulted in the increase in the $\mathrm{S} / \mathrm{G}$ ratio) but was also accompanied by abnormal growth, such as plant dwarfism [50]. The CCR gene of deficient Arabidopsis mutant irx4 [51] also showed a similar situation, that is, a decrease in lignin content (50\% of that of the wild type) and abnormal plant growth. It can be seen that inhibition of $C C R$ activity alone can reduce the biosynthesis of lignin and affect the growth and development of plants. $\mathrm{F} 5 \mathrm{H}$ is one of the key enzymes in lignin biosynthesis, which may be the control point of S-lignin synthesis. The Arabidopsis mutant fah1, lacking F5H activity, has the same phenotype as the wild type, and its lignin contains only $\mathrm{G}$ lignin [52]. The content of s-lignin in transgenic tobacco and Arabidopsis overexpressed with $\mathrm{F} 5 \mathrm{H}$ increased significantly, whereas g-lignin biosynthesis was inhibited significantly [53,54]. HCT is a recently studied enzyme in the biosynthetic pathway of lignin. In Arabidopsis thaliana, HCT gene silencing resulted in plant dwarfing, decreased lignin content, and composition changes [55]. Studies in Pinus radiata [56] and Medicago sativa [57] showed that changes in HCT gene expression levels can affect lignin synthesis and content levels in plants. The transgenic Medicago sativa lines with downregulation of HCT expression showed a phenotype with a significant decrease in lignin content, growth retardation, and biomass reduction [57]. Compared with WT, the expression levels of CCR (DEP), F5H (DEP), and HCT (DEP) were downregulated in T51, which is consistent with the lower lignin content in the leaves (Figure 4A). Lignin is a component of the plant secondary cell wall. The differential expression of lignin content and the lignin synthesis gene in T51 may lead to changes in the T51 cell wall structure. Therefore, we speculate that the changes in the expression of the above proteins change the composition and structure of lignin and then affect the plant type of T51, which is closely related to the dwarf phenotype of T51 (Figure 5). 


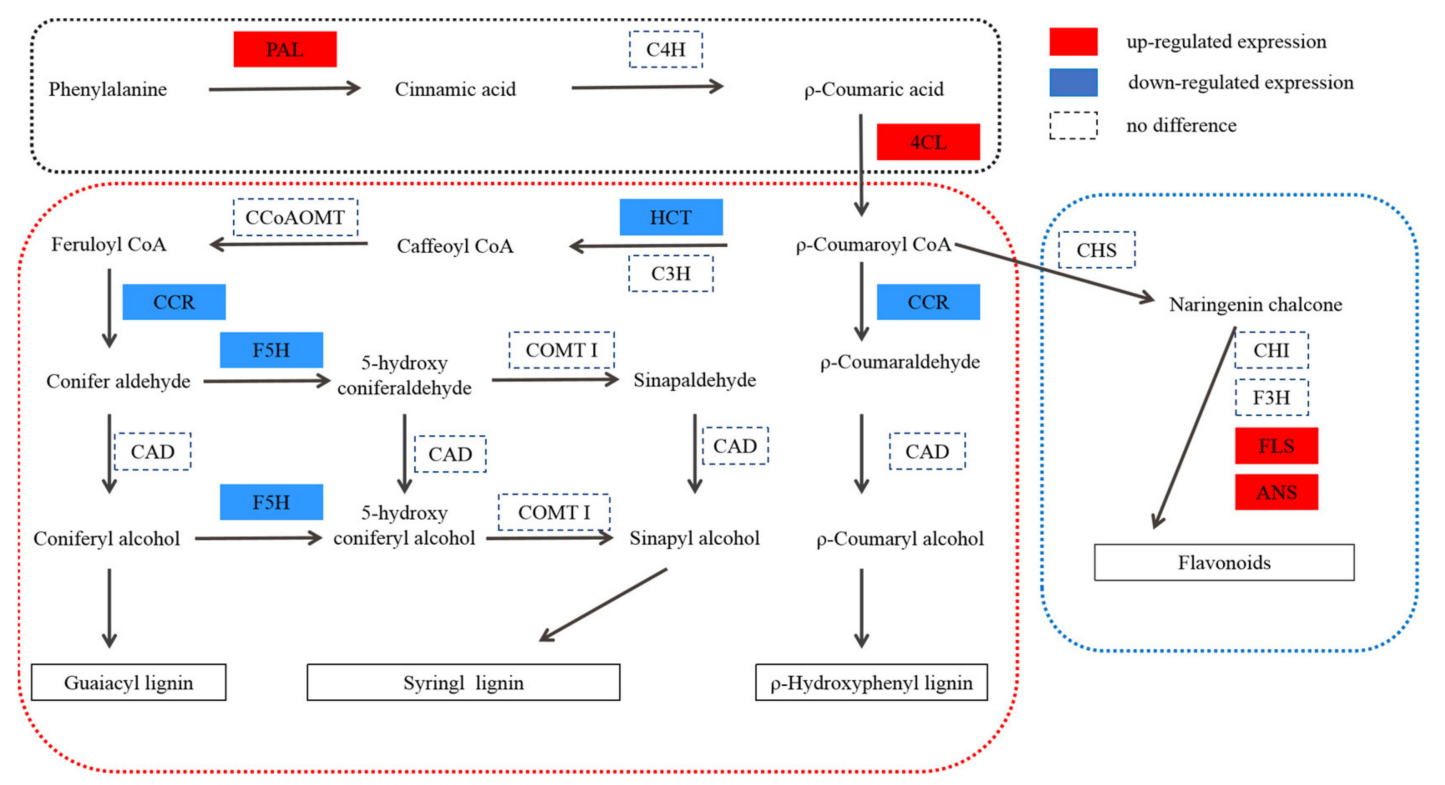

Figure 5. Protein expression patterns of phenylpropane pathway in T51. P-coumaroyl CoA is at the crossroads of metabolic routes leading either to flavonoids or to monolignols. $P$-coumaroyl $\mathrm{CoA}$ is at the crossroads of metabolic routes leading either to flavonoids or to monolignols. PAL, phenylalanine ammonia lyase; C4H, C4-hydroxylase (CYP73A5); 4CL, 4coumaroyl-CoA ligase; CHS, chalcone synthase; $\mathrm{CHI}$, chalcone isomerase; F3H, flavanone 3-hydroxylase; FLS, flavonol synthase; ANS, anthocyanidin synthase; HCT, hydroxycinnamoyl CoA:shikimate hydroxycinnamoyl transferase; $\mathrm{C} 3 \mathrm{H}$, C3-hydroxylase (CYP98A3); CCR, cinnamoyl-CoA reductase; CAD, cinnamyl alcohol dehydrogenase; F5H, ferulate 5hydroxylase (CYP84A1); CCoAOMT, caffeoyl-CoA O-methyltransferase; COMT I, caffeic acid O-methyltransferase of class I.

Flavonol synthase (FLS) [58] and anthocyanidin synthase (ANS) [59] are key enzymes in flavonoid biosynthesis. Compared with WT, the expression levels of FLS and ANS (Table S4) were upregulated in T51, which caused the flavonoid content to be higher in T51 than in WT (Figure 4B). Most studies indicate that flavonoids are IAA transport inhibitors [60]. Recent studies suggest that flavonoids are involved in IAA metabolism [61]. Nitrilase (NIT) is a key enzyme in the IAA synthesis pathway [62]. N-hydroxythioamide S-beta-glucosyltransferase(UGT74B1) can regulate the dynamic balance of IAA [63]. Our results reveal that proteins related to IAA synthesis are differentially expressed in T51. The protein NIT with accession no. TRINITY_DN51107_c0_g1 showed a lower expression, whereas the protein with accession no. TRINITY_DN50720_c1_g4 showed a higher expression in T51 (Table S5). Thus, we speculate that the accumulation of flavonoids in T51 possibly inhibits the polar transport of IAA, thereby changing the IAA content and ultimately leading to the dwarf phenotype compared with the control (Figure 5).

Flavonoids and lignin are the metabolites of the phenylpropanoid pathway, and a competitive relationship exists between them. The upregulation of FLS and ANS expressions, key enzymes in flavonoids synthesis, promotes the increased flow of metabolites in the direction of flavonoids synthesis, which indirectly results in a decrease of lignin synthesis. Based on the above results, we propose a T51 dwarfing mechanism hypothesis; the abnormal synthesis of flavonoids and lignin leads to the abnormal polar transport of IAA and changes in the cell wall, finally leading to the dwarfing of T51.

\section{Materials and Methods}

\subsection{Plant Materials}

The dwarf mutant T51 of seashore paspalum was obtained by chemical mutagenesis using Sea Spray. After several years of field observation, the T51 dwarf phenotype was stable, so it was used in this study. 
This study was conducted in June 2020 in the Nanjing Agricultural University turf grass germplasm resource garden located in Nanjing, Jiangsu Province, China. The stolons of T51 (induced by Sea Spray) and WT (Sea Spray) were planted in $11 \mathrm{~cm}$ diameter and $21 \mathrm{~cm}$ deep containers. The soil mixture was a 1:1:1 ratio of sand, soil, and perlite. Seashore paspalum plants were watered and fertilized as needed. T51 and WT each had 6 replicates. The mature leaves were used for the sequencing studies. Every 2 pots were used as repetitions, and 3 repetitions were collected for RNA-Seq and iTRAQ. The mature leaves were immediately frozen in liquid nitrogen for $30 \mathrm{~min}$ and stored at $-80^{\circ} \mathrm{C}$ until use.

\subsection{Phenotypic Characterization}

Plant height was considered as the natural growth height of the plant, measured with a tape measure; 10 plants were randomly selected from each treatment. Leaf length and width were measured with a Vernier caliper, and 10 plants were randomly selected from each treatment. The diameter and length of the stem were measured using a Vernier caliper, and 10 plants were randomly selected from each treatment.

\subsection{RNA Isolation, Quantification, and Qualification}

The total RNA of each sample (WT-1, WT-2, WT-3, T51-1, T51-2, and T51-3) was isolated using the RNAprep Pure Plant Kit (Tiangen Biotech, Beijing, China) according to the user manual. A Nanodrop2000 was used to detect the purity of the RNA (OD $260 / 280$ ), and the quality of each RNA sample was checked on $1 \%$ agarose gel. Additionally, RNA with an RNA integrity number $>8$ according to the 2100 Bioanalyzer (Agilent, Palo Alto, CA, USA) was used to prepare cDNA libraries with an RNA Library Prep Kit (Illumina, San Diego, CA, USA). The resulting libraries were sequenced on a HiSeq2000 platform (Illumina), 15 November 2020.The data (raw reads) obtained from the Illumina sequencing were uploaded in the NCBI Sequence Read Archive (SRA) (accession number, PRJNA760252).

\subsection{Gene Function Annotation}

The functions of the unigenes were annotated using a series of databases, including BLASTx, against the NCBI non-redundant protein $(\mathrm{Nr})$, NCBI nucleotide collection $(\mathrm{Nt})$, and Swiss-Prot databases. Functional categories of putative unigenes were grouped using the Kyoto Encyclopedia of Genes and Genomes (KEGG, http:/ / www.genome.jp/kegg/; accessed on 25 November 2020), the Clusters of Orthologous Groups of proteins (KOG/COG, http://www.ncbi.nlm.nih.gov/COG/; accessed on 29 November 2020) database, and Blast2GO against Gene Ontology (GO, http: / /www.geneontology.org; accessed on 4 December 2020).

\subsection{Differential Expression Analysis}

Clean reads were aligned against the assembled transcript to generate read counts using the RSEM package. The read count of each unigene was converted into FPKM values to normalize the gene expression using the FPKM method. The EdgeR package was used to analyze the differential expression of two conditions (three biological replicates per condition). Genes with an adjusted FDR $<0.05$ and $\mid \log _{2}$ fold-change $\mid>1$ found by EdgeR were designated as differentially expressed. Gene Ontology (GO) enrichment analysis of differentially expressed genes was performed using the GOseq $\mathrm{R}$ package. KOBAS software was used to find the statistical enrichment of KEGG pathways in the differentially expressed genes.

\subsection{Protein Extraction and Protein Quantification}

The sample tissue was washed with cold PBS; liquid nitrogen was fully ground, and the ground powder was transferred to a centrifuge tube. We added an appropriate amount of lysis buffer to RIPA solution containing a final concentration of $1 \%$ PMSF, which was placed in an ice bath, subjected to ultrasound for $5 \mathrm{~min}(3 \mathrm{~s} / 5 \mathrm{~s})$, then centrifuged 
at $12,000 \times \mathrm{g}$ for $10 \mathrm{~min}$ at $4^{\circ} \mathrm{C}$. We then removed the supernatant, added $100 \%$ TCA solution dropwise to the final TCA concentration of $20 \%$, and mixed it evenly. We then added an equal sample volume of $\mathrm{CHCl}$, mixed well, placed the solution on ice for $1 \mathrm{~h}$, vortexing every $20 \mathrm{~min}$, and then centrifuged it at $1500 \times \mathrm{g}$ for $10 \mathrm{~min}$. After precipitation was complete, we removed the supernatant liquid; the middle layer was the protein precipitate, and the lower layer was $\mathrm{CHCl} 3$ solution. We added $100 \mu \mathrm{L}$ water and $100 \mu \mathrm{L}$ methanol solution to the supernatant, centrifuged at $1500 \times g$ for $10 \mathrm{~min}$, then removed the supernatant after centrifugation and adjusted the $\mathrm{pH}$ to 2-3 with $1 \mathrm{M}$ TEAB.

We took $2 \mu \mathrm{L}$ of protein sample, diluted it to an appropriate multiple, and determined the protein concentration by the Bradford method as follows: $2 \mathrm{~mL}$ of $0.02 \mu \mathrm{g} / \mu \mathrm{L}$ BSA standard was configured; BSA standards (0, 20,40, 60, 80, 100, 120, 140, 160, 180, and $200 \mu \mathrm{L}$ ) were placed into a new $1.5 \mathrm{~mL}$ EP tube. We added the diluent to a final volume of $200 \mu \mathrm{L}$ and mixed well. We placed $20 \mu \mathrm{L}$ of the diluted BSA solution onto the microplate and set up 3 replicate wells for each concentration. We added $20 \mu \mathrm{L}$ of the diluted protein sample to the microplate and set up 3 replicate wells for each sample. We added $180 \mu \mathrm{L}$ of G250 color-developing solution to each well and developed the wells at room temperature in the dark for $5 \mathrm{~min}$. A microplate reader was used to determine the A580 absorbance value. We calculated the concentration of the protein sample based on the standard curve and the dilution factor of the protein sample.

\subsection{Enzyming and Desalting}

We took $100 \mu \mathrm{g}$ of protein and used U2 lysis buffer to dissolve it to about $1 \mu \mathrm{g} / \mu \mathrm{L}$. We added 5 volumes of $100 \mathrm{mM}$ TEAB and diluted the protein 6-fold. We added $1.2 \mu \mathrm{L} 0.5 \mathrm{M}$ $\mathrm{CaCl}_{2}$ and centrifuged by shaking. We then added trypsin digestion (trypsin/protein =1:100) and incubated at $37^{\circ} \mathrm{C}$ for more than $8 \mathrm{~h}$. We weighed $10 \mathrm{mg}$ of $\mathrm{C} 18$ column material, corresponding to every $100 \mu \mathrm{g}$ of peptide sample. We activated the column material with $1 \mathrm{~mL}$ methanol, centrifuged with shaking, and discarded the supernatant. We added $1 \mathrm{~mL}$ $0.1 \%$ FA to acidify, then centrifuged and discarded the supernatant. Peptide samples were acidified with an equal volume of $0.1 \%$ FA, shaken, vortexed into a centrifuge tube, mixed quietly for $30 \mathrm{~min}$, and centrifuged to discard the supernatant. The sample was then washed twice with $0.1 \%$ FA and 3\% ACN for desalting and eluted with $1 \mathrm{~mL} 0.1 \%$ FA and 80\% ACN. The eluted peptide was dried with a vacuum concentrator.

\subsection{ITRAQ Labeling and Fractionation}

We dissolved the peptide sample in $20 \mu \mathrm{L}$ dissolution buffer (0.5 M TEAB), added $70 \mu \mathrm{L}$ isopropanol, and centrifuged with shaking. Samples were labeled with an iTRAQ Reagent-8 plex Multiplex Kit (AB SCIEX, Waltham, MA, USA) according to the manufacturer's instructions. All the labeled samples were mixed in equal amounts. Next, the labeled samples were fractionated using a high-performance liquid chromatography (HPLC) system (Thermo, Waltham, MA, USA) using a Welch C18 (5 $\mu \mathrm{m}, 100 \mathrm{~A}, 4.6 \times 250 \mathrm{~mm})$ at high $\mathrm{pH}$ conditions. Lastly, collected fractions were combined into 12 fractions. The combined components were desalted on a Strata-X column and dried in vacuo.

\subsection{LC-MS/MS Analysis}

Peptide samples were diluted to $1 \mu \mathrm{g} / \mu \mathrm{L}$ using on-board buffer, the sample volume was set to $8 \mu \mathrm{L}$, and the scanning mode was $90 \mathrm{~min}$. We scanned the peptides with a massto-charge ratio of 350-1200 in the sample. A Triple TOF $5600+$ LC / MS system (AB SCIEX, Waltham, MA, USA) was used for mass spectrometry data acquisition. The peptide samples were dissolved in $2 \%$ acetonitrile $/ 0.1 \%$ formic acid and analyzed using a Triple TOF 5600+ mass spectrometer coupled with an Eksigent nanoLC System (AB SCIEX, Waltham, MA, USA). Peptide was loaded onto a C18 trap column $(3 \mu \mathrm{m}, 350 \mu \mathrm{m} \times 50 \mathrm{~mm})$ and eluted at $300 \mathrm{~nL} / \mathrm{min}$ onto a C18 analytical column $(3 \mu \mathrm{m}, 75 \mu \mathrm{m} \times 150 \mathrm{~mm})$ over a 90 min gradient. The two mobile phases were buffer $\mathrm{A}\left(2 \%\right.$ acetonitrile $/ 0.1 \%$ formic acid $\left./ 98 \% \mathrm{H}_{2} \mathrm{O}\right)$ and buffer $\mathrm{B}\left(98 \%\right.$ acetonitrile/0.1\% formic acid/2\% $\left.\mathrm{H}_{2} \mathrm{O}\right)$. For information-dependent 
acquisition (IDA), survey scans were acquired in $250 \mathrm{~ms}$, and 40 product ion scans were collected at $50 \mathrm{~ms} / \mathrm{scan}$. MS1 spectra were collected in the range of $350-1500 \mathrm{~m} / \mathrm{z}$, and MS2 spectra were collected in the range of 100-1500 m/z. Precursor ions were excluded from reselection for $15 \mathrm{~s}$.

\subsection{Proteomic Database Search}

Proteinpilot 4.5 software (July 2012; ab SCIEX) was used to retrieve and analyze the mass spectrometer data. Each MS/MS spectrum was searched against a deduced protein database from RNA-Seq. The retrieval parameters were set as follows: type of search, iTRAQ 8plex (peptide labeled); enzyme, trypsin; cys alkylation, iodoacetamide; instrument, Triple TOF 5600; bias correction, TRUE; Background Correction, TRUE; ID focus, biological modifications; search effort, thorough ID; protein mass, unrestricted; detected protein threshold (unused score $\geq 1.3$ ); No. distinct peptides (confidence) $\geq 95 \%$. The average relative expression (fold-change ratios of differential expression between labeled protein samples), P-value, error factor, lower confidence interval, and upper confidence interval were calculated by Protein Pilot and then exported into Excel. Proteins with fold-change ratios of $\geq 1.5$ or $\leq 0.67$ and $p$-values of $\leq 0.05$ were considered to be differentially expressed proteins (DEPs).

\subsection{1. qRT-PCR Analysis for Validation}

To validate the RNA-Seq data analysis, the total RNA used for sequencing was also used for qRT-PCR analysis for each biological replicate. Total RNA was used as the template for cDNA synthesis with reverse transcriptase (Takara Bio, Kusatsu, Japan) following the manufacturer's instructions. qPCR and data analysis, with actin used as a reference gene to normalize gene expression, were performed as described by Wang et al. [64]. Six differentially expressed genes from RNA-Seq were validated.

\subsection{Measurement of Klason Lignin and Flavonoid Contents}

T51 and WT leaves were collected to determine the Klason lignin and flavonoid contents. Samples for measuring the Klason lignin and flavonoid contents were prepared according to the protocol of Hames et al. [65], and the contents were determined according to the protocol of Sluiter et al. [66]. Flavonoid contents were measured using the method of Quettier-Deleu et al. [67].

Phenotypic variation, correlation, and linear regression analyses were completed using SPSS (version 19.0) (IBM Corp., Armonk, NY, USA).

\section{Conclusions}

In summary, our findings suggest that the dwarfing of T51 is due to the abnormal synthesis of lignin and flavonoids in the phenylpropane pathway. Combined with the changes in the transcription and protein levels, we propose that CCR (TRINITY_DN42134_c0_g1) and HCT (TRINITY_DN50277_c0_g1) are candidate genes related to the dwarfing of the phenylpropanoid pathway in T51.

Supplementary Materials: Supplementary Materials can be found at https://www.mdpi.com/ article/10.3390/ijms22179568/s1.

Author Contributions: Y.Z. and Z.Y. designed the study. Y.Z. performed the experiment and wrote the manuscript. J.L., J.Y. and H.Z. collected the samples, Y.Z. and Z.Y. analyzed the data.Y.Z. edited the manuscript draft. All authors have read and agreed to the published version of the manuscript.

Funding: The present research was supported by National Natural Science Foundation of China (31872953)

Data Availability Statement: Not applicable.

Acknowledgments: The plant materials were provided by Jun Liu; RNA-seq and iTRAQ were completed by Wuhan Gene Create Biological Engineering Co., Ltd. 
Conflicts of Interest: The authors declare no conflict of interest.

\section{References}

1. Lv, C.C.; Luo, L.X.; Li, J.Q.; Hsiang, T. First Report of Dollar Spot of Seashore Paspalum (Paspalum vaginatum) Caused by Sclerotinia homoeocarpa in South China. Plant Dis. 2010, 94, 373. [CrossRef]

2. Cyril, J.; Powell, G.; Duncan, R.; Baird, W. Changes in membrane polar lipid fatty acids of seashore paspalum in response to low temperature exposure. Crop Sci. 2002, 42, 2031-2037. [CrossRef]

3. Lee, G.; Carrow, R.N.; Duncan, R.R. Salinity tolerance of selected seashore paspalums and bermudagrasses: Root and verdure responses and criteria. HortScience 2004, 39, 1143-1147. [CrossRef]

4. Ashikari, M.; Wu, J.; Yano, M.; Sasaki, T.; Yoshimura, A. Rice gibberellin-insensitive dwarf mutant gene Dwarf 1 encodes the $\alpha$-subunit of GTP-binding protein. Proc. Natl. Acad. Sci. USA 1999, 96, 10284-10289. [CrossRef]

5. Zwar, J.A.; Chandler, P.M. $\alpha$-Amylase production and leaf protein synthesis in a gibberellin-responsive dwarf mutant of 'Himalaya'barley (Hordeum vulgare L.). Planta 1995, 197, 39-48. [CrossRef]

6. Fridborg, I.; Kuusk, S.; Moritz, T.; Sundberg, E. The Arabidopsis dwarf mutant shi exhibits reduced gibberellin responses conferred by overexpression of a new putative zinc finger protein. Plant Cell 1999, 11, 1019-1031. [CrossRef] [PubMed]

7. Takahashi, N.; Nakazawa, M.; Shibata, K.; Yokota, T.; Ishikawa, A.; Suzuki, K.; Kawashima, M.; Ichikawa, T.; Shimada, H.; Matsui, M. shk1-D, a dwarf Arabidopsis mutant caused by activation of the CYP72C1 gene, has altered brassinosteroid levels. Plant J. 2005, 42, 13-22. [CrossRef] [PubMed]

8. Tanabe, S.; Ashikari, M.; Fujioka, S.; Takatsuto, S.; Yoshida, S.; Yano, M.; Yoshimura, A.; Kitano, H.; Matsuoka, M.; Fujisawa, Y. A novel cytochrome P450 is implicated in brassinosteroid biosynthesis via the characterization of a rice dwarf mutant, dwarf11, with reduced seed length. Plant Cell 2005, 17, 776-790. [CrossRef] [PubMed]

9. Gao, Z.; Qian, Q.; Liu, X.; Yan, M.; Feng, Q.; Dong, G.; Liu, J.; Han, B. Dwarf 88, a novel putative esterase gene affecting architecture of rice plant. Plant Mol. Biol. 2009, 71, 265-276. [CrossRef]

10. Zhang, J.; Liu, X.; Li, S.; Cheng, Z.; Li, C. The rice semi-dwarf mutant sd37, caused by a mutation in CYP96B4, plays an important role in the fine-tuning of plant growth. PLoS ONE 2014, 9, e88068. [CrossRef]

11. Dixon, R.A.; Paiva, N.L. Stress-induced phenylpropanoid metabolism. Plant Cell 1995, 7, 1085. [CrossRef] [PubMed]

12. Song, J.; Wang, Z. RNAi-mediated suppression of the phenylalanine ammonia-lyase gene in Salvia miltiorrhiza causes abnormal phenotypes and a reduction in rosmarinic acid biosynthesis. J. Plant Res. 2011, 124, 183-192. [CrossRef] [PubMed]

13. Tanaka, H.; Masuta, C.; Uehara, K.; Kataoka, J.; Koiwai, A.; Noma, M. Morphological changes and hypomethylation of DNA in transgenic tobacco expressing antisense RNA of the S-adenosyl-L-homocysteine hydrolase gene. Plant Mol. Biol. 1997, 35, 981-986. [CrossRef]

14. Moffatt, B.A.; Stevens, Y.Y.; Allen, M.S.; Snider, J.D.; Pereira, L.A.; Todorova, M.I.; Summers, P.S.; Weretilnyk, E.A.; Martin-McCaffrey, L.; Wagner, C. Adenosine kinase deficiency is associated with developmental abnormalities and reduced transmethylation. Plant Physiol. 2002, 128, 812-821. [CrossRef] [PubMed]

15. Schoor, S.; Farrow, S.; Blaschke, H.; Lee, S.; Perry, G.; von Schwartzenberg, K.; Emery, N.; Moffatt, B. Adenosine kinase contributes to cytokinin interconversion in Arabidopsis. Plant Physiol. 2011, 157, 659-672. [CrossRef]

16. Trabucco, G.M.; Matos, D.A.; Lee, S.J.; Saathoff, A.J.; Priest, H.D.; Mockler, T.C.; Sarath, G.; Hazen, S.P. Functional characterization of cinnamyl alcohol dehydrogenase and caffeic acid O-methyltransferase in Brachypodium distachyon. BMC Biotechnol. 2013, 13, 61. [CrossRef]

17. Besseau, S.; Hoffmann, L.; Geoffroy, P.; Lapierre, C.; Pollet, B.; Legrand, M. Flavonoid accumulation in Arabidopsis repressed in lignin synthesis affects auxin transport and plant growth. Plant Cell 2007, 19, 148-162. [CrossRef]

18. Wang, Z.; Cui, L.; Chen, C.; Liu, X.; Yan, Y.; Wang, Z. Downregulation of cinnamoyl CoA reductase affects lignin and phenolic acids biosynthesis in Salvia miltiorrhiza Bunge. Plant Mol. Biol. Report. 2012, 30, 1229-1236. [CrossRef]

19. Duan, J.; Xia, C.; Zhao, G.; Jia, J.; Kong, X. Optimizing de novo common wheat transcriptome assembly using short-read RNA-Seq data. BMC Genom. 2012, 13, 392. [CrossRef]

20. Schreiber, A.W.; Hayden, M.J.; Forrest, K.L.; Kong, S.L.; Langridge, P.; Baumann, U. Transcriptome-scale homoeolog-specific transcript assemblies of bread wheat. BMC Genom. 2012, 13, 492. [CrossRef]

21. Krasileva, K.V.; Buffalo, V.; Bailey, P.; Pearce, S.; Ayling, S.; Tabbita, F.; Soria, M.; Wang, S.; Akhunov, E.; Uauy, C. Separating homeologs by phasing in the tetraploid wheat transcriptome. Genome Biol. 2013, 14, R66. [CrossRef]

22. Gan, L.; Di, R.; Chao, Y.; Han, L.; Chen, X.; Wu, C.; Yin, S. De novo transcriptome analysis for Kentucky Bluegrass dwarf mutants induced by space mutation. PLOS ONE 2016, 11, e0151768.

23. Xie, Y.; Niu, X.; Jiang, X.; Liu, S.; Wang, M. Comparison of alternative splicing of Brassica napus dwarf mutant and its tall-stalked parents by using RNA-seq. Chin. J. Appl. Environ. Biol. 2018, 24, 81-88.

24. Ou, C.; Jiang, S.; Wang, F.; Tang, C.; Hao, N. An RNA-Seq analysis of the pear (Pyrus communis L.) transcriptome, with a focus on genes associated with dwarf. Plant Gene 2015, 4, 69-77. [CrossRef]

25. Wang, F.; Bai, M.Y.; Deng, Z.; Oses-Prieto, J.A.; Burlingame, A.L.; Lu, T.; Chong, K.; Wang, Z.Y. Proteomic study identifies proteins involved in brassinosteroid regulation of rice growth. J. Integr. Plant Biol. 2010, 52, 1075-1085. [CrossRef]

26. Tu, X.; Li, J.; Wang, Q.; Liu, A. Quantitative proteomic analysis of upland cotton stem terminal buds reveals phytohormone-related pathways associated with dwarfism. Biol. Plant. 2017, 61, 106-114. [CrossRef] 
27. Wang, Y.; Xiao, X.; Wang, X.; Zeng, J.; Kang, H.; Fan, X.; Sha, L.; Zhang, H.; Zhou, Y. RNA-Seq and iTRAQ reveal the dwarfing mechanism of dwarf polish wheat (Triticum polonicum L.). Int. J. Biol. Sci. 2016, 12, 653. [CrossRef]

28. Zeller, M.; Blackburn, M.L.; Scigelova, M.; Sun, Y.; Delanghe, B. P217-S Relative Quantitation of iTRAQ-Labeled Proteins Using IRMPD on an LTQ FT Ultra. J. Biomol. Tech. 2007, 18, 75.

29. Wu, W.W.; Wang, G.; Baek, S.J.; Shen, R.-F. Comparative study of three proteomic quantitative methods, DIGE, cICAT, and iTRAQ, using 2D gel-or LC- MALDI TOF/TOF. J. Proteome Res. 2006, 5, 651-658. [CrossRef] [PubMed]

30. Looso, M.; Preussner, J.; Sousounis, K.; Bruckskotten, M.; Michel, C.S.; Lignelli, E.; Reinhardt, R.; Höffner, S.; Krüger, M.; Tsonis, P.A. A de novo assembly of the newt transcriptome combined with proteomic validation identifies new protein families expressed during tissue regeneration. Genome Biol. 2013, 14, R16. [CrossRef]

31. Tse, W.K.F.; Sun, J.; Zhang, H.; Law, A.Y.S.; Yeung, B.H.Y.; Chow, S.C.; Qiu, J.-W.; Wong, C.K.C. Transcriptomic and iTRAQ proteomic approaches reveal novel short-term hyperosmotic stress responsive proteins in the gill of the Japanese eel (Anguilla japonica). J. Proteom. 2013, 89, 81-94. [CrossRef] [PubMed]

32. Jing, Z.B.; Wei, L.; Jing, Y.U.; Cheng, J.M. Transcription sequencing and its application prospective on discovering the gene resources of forages. Pratacultural Sci. 2011, 28, 1364-1369.

33. Wu, P.; Cogill, S.; Qiu, Y.; Li, Z.; Zhou, M.; Hu, Q.; Chang, Z.; Noorai, R.E.; Xia, X.; Saski, C. Comparative transcriptome profiling provides insights into plant salt tolerance in seashore paspalum (Paspalum vaginatum). BMC Genom. 2020, 21, 131. [CrossRef]

34. Luo, X.; Cao, D.; Li, H.; Zhao, D.; Xue, H.; Niu, J.; Chen, L.; Zhang, F.; Cao, S. Complementary iTRAQ-based proteomic and RNA sequencing-based transcriptomic analyses reveal a complex network regulating pomegranate (Punica granatum L.) fruit peel colour. Sci. Rep. 2018, 8, 12362. [CrossRef]

35. Li, L.-Q.; Zou, X.; Deng, M.-S.; Peng, J.; Huang, X.-L.; Lu, X.; Fang, C.-C.; Wang, X.-Y. Comparative morphology, transcription, and proteomics study revealing the key molecular mechanism of camphor on the potato tuber sprouting effect. Int. J. Mol. Sci. 2017, 18, 2280. [CrossRef]

36. Chen, J.; Liu, S.; Kohler, A.; Bo, Y.; Guo, S.X. iTRAQ and RNA-Seq Analyses Provide New Insights into Regulation Mechanism of Symbiotic Germination of Dendrobium officinale Seeds (Orchidaceae). J. Proteome Res. 2017, 16, 2174-2187. [CrossRef]

37. Pandey, A.; Mann, M. Proteomics to study genes and genomes. Nature 2000, 405, 837-846. [CrossRef] [PubMed]

38. Muers, M. Transcriptome to proteome and back to genome. Nat. Rev. Genet. 2011, 12, 518. [CrossRef] [PubMed]

39. Anterola, A.M.; Lewis, N.G. Trends in lignin modification: A comprehensive analysis of the effects of genetic manipulations / mutations on lignification and vascular integrity. Phytochemistry 2002, 61, 221-294. [CrossRef]

40. Khan, W.; Prithiviraj, B.; Smith, D.L. Chitosan and chitin oligomers increase phenylalanine ammonia-lyase and tyrosine ammonialyase activities in soybean leaves. J. Plant Physiol. 2003, 160, 859-863. [CrossRef]

41. Liang, X.; Dron, M.; Cramer, C.; Dixon, R.A.; Lamb, C.J. Differential regulation of phenylalanine ammonia-lyase genes during plant development and by environmental cues. J. Biol. Chem. 1989, 264, 14486-14492. [CrossRef]

42. Rohde, A.; Morreel, K.; Ralph, J.; Goeminne, G.; Hostyn, V.; De Rycke, R.; Kushnir, S.; Van Doorsselaere, J.; Joseleau, J.-P.; Vuylsteke, M. Molecular phenotyping of the pal1 and pal2 mutants of Arabidopsis thaliana reveals far-reaching consequences on phenylpropanoid, amino acid, and carbohydrate metabolism. Plant Cell 2004, 16, 2749-2771. [CrossRef]

43. Elkind, Y.; Edwards, R.; Mavandad, M.; Hedrick, S.A.; Ribak, O.; Dixon, R.A.; Lamb, C.J. Abnormal plant development and down-regulation of phenylpropanoid biosynthesis in transgenic tobacco containing a heterologous phenylalanine ammonia-lyase gene. Proc. Natl. Acad. Sci. USA 1990, 87, 9057-9061. [CrossRef] [PubMed]

44. Bate, N.J.; Orr, J.; Ni, W.; Meromi, A.; Nadler-Hassar, T.; Doerner, P.W.; Dixon, R.A.; Lamb, C.J.; Elkind, Y. Quantitative relationship between phenylalanine ammonia-lyase levels and phenylpropanoid accumulation in transgenic tobacco identifies a rate-determining step in natural product synthesis. Proc. Natl. Acad. Sci. USA 1994, 91, 7608-7612. [CrossRef] [PubMed]

45. Huang, J.; Gu, M.; Lai, Z.; Fan, B.; Shi, K.; Zhou, Y.-H.; Yu, J.-Q.; Chen, Z. Functional analysis of the Arabidopsis PAL gene family in plant growth, development, and response to environmental stress. Plant Physiol. 2010, 153, 1526-1538. [CrossRef] [PubMed]

46. Sutela, S.; Hahl, T.; Tiimonen, H.; Aronen, T.; Ylioja, T.; Laakso, T.; Saranpää, P.; Chiang, V.; Julkunen-Tiitto, R.; Häggman, H. Phenolic compounds and expression of 4CL genes in silver birch clones and Pt4CL1a lines. PLoS ONE 2014, 9, e114434. [CrossRef] [PubMed]

47. Lee, D.; Meyer, K.; Chapple, C.; Douglas, C. Down-regulation of 4-coumarate: CoA ligase (4CL) in Arabidopsis: Effect on lignin composition and implications for the control of monolignol biosynthesis. Plant Cell 1997, 9, 1985-1998.

48. Kajita, S.; Katayama, Y.; Omori, S. Alterations in the Biosynthesis of Lignin in Transgenic Plants with Chimeric Genes for 4-Coumarate: Coenzyme A Ligase. Plant Cell Physiol. 1996, 37, 957-965. [CrossRef]

49. Rest, B.V.D.; Danoun, S.; Rochange, B.S.F. Down-regulation of cinnamoyl-CoA reductase in tomato (Solanum lycopersicum L.) induces dramatic changes in soluble phenolic pools. J. Exp. Bot. 2006, 57, 1399. [CrossRef]

50. Piquemal, J.; Lapierre, C.; Myton, K.; O'connell, A.; Schuch, W.; Grima-Pettenati, J.; Boudet, A.-M. Down-regulation of cinnamoylCoA reductase induces significant changes of lignin profiles in transgenic tobacco plants. Plant J. 1998, 13, 71-83. [CrossRef]

51. Jones, L.; Ennos, A.R.; Turner, S.R. Cloning and characterization of irregular xylem4 (irx4): A severely lignin-deficient mutant of Arabidopsis. Plant J. 2001, 26, 205-216. [CrossRef]

52. Chapple, C.; Vogt, T.; Ellis, B.E.; Somerville, C.R. An Arabidopsis mutant defective in the general phenylpropanoid pathway. Plant Cell 1992, 4, 1413-1424. 
53. Franke, R.; McMichael, C.M.; Meyer, K.; Shirley, A.M.; Cusumano, J.C.; Chapple, C. Modified lignin in tobacco and poplar plants over-expressing the Arabidopsis gene encoding ferulate 5-hydroxylase. Plant J. 2000, 22, 223-234. [CrossRef]

54. Sibout, R.; Baucher, M.; Gatineau, M.; Van Doorsselaere, J.; Mila, I.; Pollet, B.; Maba, B.; Pilate, G.; Lapierre, C.; Boerjan, W. Expression of a poplar cDNA encoding a ferulate-5-hydroxylase/coniferaldehyde 5-hydroxylase increases $\mathrm{S}$ lignin deposition in Arabidopsis thaliana. Plant Physiol. Biochem. 2002, 40, 1087-1096. [CrossRef]

55. Hoffmann, L.; Besseau, S.; Geoffroy, P.; Ritzenthaler, C.; Meyer, D.; Lapierre, C.; Pollet, B.; Legrand, M. Silencing of hydroxycinnamoyl-coenzyme A shikimate/quinate hydroxycinnamoyltransferase affects phenylpropanoid biosynthesis. Plant Cell 2004, 16, 1446-1465. [CrossRef] [PubMed]

56. Wagner, A.; Ralph, J.; Akiyama, T.; Flint, H.; Phillips, L.; Torr, K.; Nanayakkara, B.; Te Kiri, L. Exploring lignification in conifers by silencing hydroxycinnamoyl-CoA: Shikimate hydroxycinnamoyltransferase in Pinus radiata. Proc. Natl. Acad. Sci. USA 2007, 104, 11856-11861. [CrossRef] [PubMed]

57. Shadle, G.; Chen, F.; Reddy, M.S.; Jackson, L.; Nakashima, J.; Dixon, R.A. Down-regulation of hydroxycinnamoyl CoA: Shikimate hydroxycinnamoyl transferase in transgenic alfalfa affects lignification, development and forage quality. Phytochemistry 2007, 68, 1521-1529. [CrossRef]

58. Preu, A.; Stracke, R.; Weisshaar, B.; Hillebrecht, A.; Matern, U.; Martens, S. Arabidopsis thaliana expresses a second functional flavonol synthase. Febs Lett. 2009, 583, 1981-1986. [CrossRef]

59. Shimada, S.; Inoue, Y.T.; Sakuta, M. Anthocyanidin synthase in non-anthocyanin-producing Caryophyllales species. Plant J. 2005, 44, 950-959. [CrossRef]

60. Luo, Z.; Murray, B.S.; Ross, A.L.; Povey, M.; Morgan, M.; Day, A.J. Effects of pH on the ability of flavonoids to act as Pickering emulsion stabilizers. Colloids Surf. B Biointerfaces 2012, 92, 84-90. [CrossRef]

61. Kuhn, B.M.; Nodzyński, T.; Errafi, S.; Bucher, R.; Gupta, S.; Aryal, B.; Dobrev, P.; Bigler, L.; Geisler, M.; Zažímalová, E. Flavonolinduced changes in PIN2 polarity and auxin transport in the Arabidopsis thaliana rol1-2 mutant require phosphatase activity. Sci. Rep. 2017, 7, 41906. [CrossRef] [PubMed]

62. Normanly, J.; Cohen, J.D.; Fink, G.R. Arabidopsis thaliana auxotrophs reveal a tryptophan-independent biosynthetic pathway for indole-3-acetic acid. Proc. Natl. Acad. Sci. USA 1993, 90, 10355-10359. [CrossRef] [PubMed]

63. Grubb, C.D.; Zipp, B.J.; Ludwig-Müller, J.; Masuno, M.N.; Molinski, T.F.; Abel, S. Arabidopsis glucosyltransferase UGT74B1 functions in glucosinolate biosynthesis and auxin homeostasis. Plant J. 2010, 40, 893-908. [CrossRef] [PubMed]

64. Wang, Y.; Wang, X.; Gu, M.; Kang, H.; Zeng, J.; Fan, X.; Sha, L.; Zhang, H.; Yu, K.; Zhou, Y. Cloning and characterization of four novel SnRK2 genes from Triticum polonicum. Biol. Plant. 2015, 59, 211-219. [CrossRef]

65. Hames, B.; Ruiz, R.; Scarlata, C.; Sluiter, A.; Sluiter, J.; Templeton, D. Preparation of samples for compositional analysis. Lab. Anal. Proced. 2008, 1617, 65-71.

66. Sluiter, A.; Hames, B.; Ruiz, R.; Scarlata, C.; Sluiter, J.; Templeton, D.; Crocker, D. Determination of structural carbohydrates and lignin in biomass. Lab. Anal. Proced. 2008, 1617, 1-16.

67. Quettier-Deleu, C.; Gressier, B.; Vasseur, J.; Dine, T.; Brunet, C.; Luyckx, M.; Cazin, M.; Cazin, J.-C.; Bailleul, F.; Trotin, F. Phenolic compounds and antioxidant activities of buckwheat (Fagopyrum esculentum Moench) hulls and flour. J. Ethnopharmacol. 2000, 72, 35-42. [CrossRef] 